\title{
Attitude of College Going Youth towards Research in Tamilnadu
}

\author{
Dr. M. Suresh Kumar*, \\ Mr. David Paul**, Mr. Vaskar Mutum***, Mr. Allwin Prabu****
}

\section{ABSTRACT:}

The present study aims to know the attitude of youth towards research in Thiruvannamalai district of Tamilnadu. The investigators adopted normative survey as a research method and adopted simple random sampling technique to draw 300 samples from various colleges. The findings of the study reveal that youth are having favourable attitude towards research and the research interest of urban area youth is better than the rural area youth.

Keywords: Attitude, Youth, Research, Tamilnadu.

\section{INTRODUCTION}

Research in India is not up to the mark of global demands in many fields. The Gross enrollment ratio of youth in higher education is $17.9 \%$ in which only 2.1 percent of them only enroll themselves in research programmes. The interest of youth should be channelized towards the research activities. It could be achieved in the very beginning of formal education. The strength of our nation depends on the teacher's ability to rear well-educated, responsible, well-adjusted youth who will step forward when the adult generation passes on to retirement. The teachers should motivate the youth to participate in research or project works in school level itself. The responsibility of teachers and institutions is to see that the youth should be strong enough to participate in research activities. This could be achieved by setting up the quality research mind among the youth.

The research enrollment in India is very less than the other developing countries and developed countries. Only very few of youth enroll in research programmes, it may be due to the lack of research aptitude, social pressure to choose a career at earlier, lack of awareness about research etc. Therefore, the investigators interested to know the attitude level of the college going youth towards research. The findings of the study will yield fruitful result on the field of higher level educational research. So, the present study has high need and importance.

\footnotetext{
*Lecturer, School of Counselling, RGNIYD

**Training Officer, RGNIYD, Tamilnadu

***Lecturer, School of youth Studies and Extension, RGNIYD

****M.Ed. Student, Tamilnadu
}

(C) 2014 S Kumar, D Paul, V Mutum, A Prabu; licensee IJIP. This is an Open Access Research distributed under the terms of the Creative Commons Attribution License (http://creativecommons.org/licenses/by/2.0), which permits unrestricted use, distribution, and reproduction in any Medium, provided the original work is properly cited. 


\section{OBJECTIVES}

The investigators of the present study framed the following objectives

1. To find out the college going youth' attitude towards research in Tiruvannamalai district.

2. To find out the significant mean difference between male and female youth with respect to attitude towards research.

3. To find out the significant mean difference between rural and urban area youth with respect to attitude towards research.

4. To find out the significant mean difference between Tamil and English medium youth with respect to attitude towards research.

5. To find out the significant mean difference between nuclear and joint family youth with respect to attitude towards research.

\section{HYPOTHESES}

The investigators of the present study framed the following hypotheses based on the objectives stated earlier

1. The college going youth' attitude towards research in Tiruvannamalai district may be favorable.

2. There is no significant mean difference between male and female youth with respect to attitude towards research.

3. There is no significant mean difference between rural and urban area youth with respect to attitude towards research.

4. There is no significant mean difference between Tamil and English medium youth with respect to attitude towards research.

5. To find out the significant mean difference between nuclear and joint family youth with respect to attitude towards research.

6.

\section{METHOD OF STUDY}

In this present study, the investigators applied normative survey as a method. The normative survey method studies, describes and interprets what exists at present.

\section{STATISTICAL TECHNIQUES}

In this present investigation the following Statistical techniques were used.

\section{Descriptive Analysis}

i) Measures of central tendency (mean)

ii) Measures of variability (standard deviation)

\section{Differential Analysis}

iii) Independent sample ' $t$ ' test 


\title{
DELIMITATIONS
}

\author{
- $\quad$ This study is confined to Tiruvannamalai district of Tamil Nadu. \\ - It is confined itself to the 300 college going youth. \\ - It is restricted to certain demographic variables only.

\section{LOCATION}

The present investigation is conducted in arts and science colleges in Tiruvannamalai district of Tamil Nadu. For this study, as many as many as nine colleges were selected for data collection.

\section{VARIABLES OF THE STUDY}

Variables are the conditions or characteristics that the researcher manipulates, controls or observes. Different variables selected by the investigators given the following sub-headings.

\section{Main variable}

The dependent variables are the conditions or characteristics that appear, disappear, or change as the researcher introduces, removes, or change independent variables. For the present study, Attitude towards research was taken as a main variable.

\section{Demographic variables}

The investigators of the present study utilized the following demographic variables, they are;
1. Gender
- Male/Female
2. Locality
- Rural/Urban
3. Medium
- Tamil/English and
4. Family Type
- Joint/Nuclear

\section{SAMPLE OF THE STUDY}

The present study consists of 300 youth studying in various colleges in Tiruvannamalai district of Tamil Nadu. The samples were selected by using simple random sampling technique.

\section{TOOL USED}

The data are necessary for carrying out research investigation if must be collected with the special instrument or devices. The successful outcome research is mainly depends upon the proper selection of the research tool. So the investigators used the attitude towards Research Scale, which was constructed and standardized by Suresh Kumar, M. [2013]

\section{DESCRIPTION OF ATTITUDE SCALE}

This scale has 29 statements, each statement in this attitude scale was set against five alternative responses, they are Strongly Agree, Agree, Undecided, Disagree and Strongly Disagree. Some of the statements in this scale worded in positively and the remaining of them worded in 
negatively. Out of 29 statements in the scale 19 of them are positively worded and the remaining 10 of them worded negatively. A score of five is given to strongly agree, four for Agree, three for undecided, two for disagree and one for strongly disagree responses in positively worded statements but the scoring is reverse for negatively worded. The maximum score for this attitude scale is 145 and the minimum score is 29.

List of positive and negative statements

\begin{tabular}{|l|l|}
\hline Positive (19) & $1,2,3,6,8,10,11,12,13,18,19,20,21,23,24,25,27,28$ and 29 \\
\hline Negative (10) & $4,5,7,9,14,15,16,17,22$ and 26 \\
\hline
\end{tabular}

\section{RELIABILITY:}

Reliability refers to the consistency with which a test measures, whatever it measures. The concept of reliability suggests both stability and consistency of measurement. The investigators calculated the reliability analysis and given below.

\begin{tabular}{|l|c|}
\hline METHOD OF RELIABILITY & RELIABILITY CO-EFFICIENTS \\
ANALYSIS & 0.712 \\
\hline Correlation between forms & 0.701 \\
\hline Equal-length Spearman-Brown & 0.791 \\
\hline Guttmann Split-half & 0.719 \\
\hline Unequal-length Spearman-Brown & \\
\hline
\end{tabular}

\section{VALIDITY:}

The Attitude towards research scale was given to the experts in order to find out its content validity. The experts agreed that the items in the scale provided adequate coverage of the concept i.e. attitude towards research.

\section{PERCENTILE NORM:}

Norms have been worked out for this scale.

\begin{tabular}{|l|l|}
\hline Score Range & Norm \\
\hline 98 and below & Unfavourable Attitude towards research \\
\hline above 98 & Favourable Attitude towards research \\
\hline
\end{tabular}

\section{ADMINISTRATION}

To collect data for the present study, the investigators administered the questionnaire individually with prior permission from the Heads of colleges in Tiruvannamalai district. The investigators given brief introduction about their research also provided adequate guidance to the 
college going youth. Whenever they face problem the researcher clarified immediately. In this manner, the investigators collected all the research tools from the selected sample.

\section{DATA ANALYSIS AND INTERPRETATION}

One of the important objectives of the present investigation is to study the attitude towards research of college going youth. For that, the investigators used a scale which was constructed by M. Suresh Kumar [2013]. The maximum score for this scale is 145 and a minimum score is 29 . Hence, one secures a score above 98 indicates favourable attitude towards research and a score below 98 indicates unfavourable attitude towards research. The computed values of entire sample and its sub-samples are given in the Table 4.1.

\section{Interpretation}

It is evident from the Table 1., the calculated mean score of entire sample of college going youth is found to be 102.80 and the standard deviation value is found to be 14.12 . The calculated mean value is higher than the percentile 50 [98]. Hence, it is inferred that the college going youth are having favourable attitude towards research.

The calculated mean score of different sub samples of college going youth is ranging from 101.96 to 104.65 . These values are higher than the percentile 50 [98]. Hence, it is inferred that irrespective of sub samples the college going youth have favoruable attitude towards research.

It is evident from the table, the calculated ' $t$ ' values are found to be $0.82,0.65,0.09$ and 1.47 respectively for gender, locality, medium and family type. These values are not significant at 0.05 level. Hence, it is inferred that the sub samples of above variable do not differ significantly in their attitude towards research. 
TABLE - 1

THE MEAN, STANDARD DEVIATION AND ' $t$ ' VALUE YOUTH IN THEIR ATTITUDE TOWARDS RESEARCH

\begin{tabular}{|c|c|c|c|c|c|c|c|}
\hline $\begin{array}{c}\text { S. } \\
\text { No. }\end{array}$ & Variable & Sample & $\mathbf{N}$ & Mean & S.D. & $\begin{array}{c}\text { 't' } \\
\text { Value }\end{array}$ & $\mathbf{L S}$ \\
\hline \multirow{2}{*}{1} & \multirow{2}{*}{ Gender } & Male & 141 & 102.08 & 13.49 & \multirow{2}{*}{0.82} & \multirow{2}{*}{ NS } \\
\hline & & Female & 159 & 103.43 & 14.69 & & \\
\hline \multirow{2}{*}{2} & \multirow{2}{*}{ Locality } & Rural & 78 & 101.96 & 12.53 & \multirow{2}{*}{0.65} & \multirow{2}{*}{ NS } \\
\hline & & Urban & 222 & 103.09 & 14.65 & & \\
\hline \multirow{2}{*}{3} & \multirow{2}{*}{ Medium } & Tamil & 165 & 102.86 & 13.82 & \multirow{2}{*}{0.09} & \multirow{2}{*}{ NS } \\
\hline & & English & 135 & 102.71 & 14.52 & & \\
\hline \multirow{2}{*}{4} & \multirow{2}{*}{ Family Type } & Nuclear & 217 & 102.09 & 14.95 & \multirow{2}{*}{1.47} & \multirow{2}{*}{ NS } \\
\hline & & Joint & 83 & 104.65 & 11.54 & & \\
\hline 5 & \multicolumn{2}{|c|}{ Entire Sample } & 300 & 102.80 & 14.12 & & \\
\hline
\end{tabular}

\section{IMPORTANT FINDINGS}

The hypotheses formulated at the beginning of the study have been examined in the light of the data gathered. The following are the main findings of the present investigation.

1. The college going youth are having favourable attitude towards research and irrespective of sub samples the college going youth have favoruable attitude towards research.

2. The male and female youth do not differ significantly in their attitude towards research.

3. The rural and urban area youth do not differ significantly in their attitude towards research. The attitude score of urban area youth is higher than the rural area youth.

4. The Tamil and English medium youth do not differ significantly in their attitude towards research.

5. The Nuclear and joint family youth do not differ significantly in their attitude towards research. 


\section{RECOMMENDATIONS}

The present study gives a clear-cut view about the present position of youth. Based on the important findings of the attitude towards research and peer group adjustment the following recommendations are made.

1. The college going youth are having favourable attitude towards research. So, the teachers and parents encourage them to achieve more in research area by allowing them to pursue quality research work in India.

2. Government should provide adequate facility to youth to get involve in quality research in arts, science, medicine, engineering and management etc.,

3. Stipend, scholarship, fellowship, financial assistance to all youth researcher should be done by the authorities in India.

4. The attitude level of urban area youth is better than the rural area youth. So, more facility should be given to both area and the government should encourage the rural area youth to participate in research activities.

5. Renowned research centres and Universities should motivate the young researcher by honouring, recognizing the young talented researchers in every year in all parts of India.

6. More career opportunities should be created to research degree holders that will motivate more youth to participate in research activities.

7. The sub samples of the present study do not show significant difference between in their attitude towards research. So, the policy makers and curriculum frame workers should consider this finding while developing research interest among the youth in this area.

\section{REFERENCES}

1. Agarwal J.C. Educational Research, New Delhi, Ariya Book Depot, (1966).

2. Aggarwal. Y.P. (1990), "Statistical methods' Concepts, Application and Computation" ( $\left.2^{\text {nd }} e d.\right)$, New Delhi, Sterling Publishers Private Ltd.

3. Buch, M.B. (1974) Forth Survey of Research in Education, Society of Educational Research and Development, Baroda.

4.Buch, M.B. (Ed.) (1986). Third Survey of Research in Education, Sri Aurobindo Marg. NCERT, New Delhi.

5. Buch, M.B., (1992) Forth Survey of Research in Education, NCERT, New Delhi.

6. Buch, M.B., (Ed) (1996-1998) Sixth Survey of Research in Education, NCERT, New Delhi 
7.Buch, M.B., (Ed.) (1974). A Survey of Research in Education, Baroda, Centre for Advanced Study in Education, M.S. University.

8.Buch, M.B., (Ed.) (1979). Second Survey of Research in Education, Baroda, Society for Educational Research and Development.

9.Carpenfer, Robert Marshall - Dissertation Abstract. International March, 1991, Vol.51, No.9, P.3014.

10. Cathrine Hildingh and Bengt Fridlund. A 3-Year Follow-Up of Participation in Peer Support Groups after a Cardiac Event. European Journal of Cardiovascular Nursing, Dec 2004; 3: 315 - 320.

11. Chauhan, S.S. "Advanced Educational Psychology", New Delhi, Uikas Publishing House, 1982.

12. Christopher Rowe and Eleanor Okell. The 'Research-Teaching Nexus' and the Learning-Teaching Relationship: Who's in charge? Arts and Humanities in Higher Education, Jun 2009; 8: 180 - 190.

13. Cornwell, Franics G (1960) "Sampling Methods", Encyclopedia of Educational Research, New York; Mc Millan Co.P.1181.

14. Dara Brodsky and C. Christopher Smith. Educational Perspectives: A Structured Approach to Teaching Medical Procedures. NeoReviews, Nov 2012; 13: e635 - e641.

15. Desh Prabhu Suchitra (2000), (Ed.) Sociological Research - Approaches, Techniques and Applications", New Delhi, Kanishka Publishers, Distributors.

16. Donald, Any et al (1979). Introduction to Research in Education, New York; Holt Rinhert and Winston.

17. En twistel N.J. and Nisbet J.P (1972) “Educational Research in Action”, University of London Press Ltd.

18. Engelhart D. Max, (1972) "Methods of Educational Research", Chicago, Rand M.C. Nally and Company.

19. Erin Marie Furtak, Tina Seidel, Heidi Iverson, and Derek C. Briggs. Experimental and Quasi-Experimental Studies of Inquiry-Based Science Teaching: A Meta-Analysis. Review of Educational Research, Sep 2012; 82: 300 - 329.

20. James E. Côté and Charles G. Levine. Attitude versus Aptitude: Is Intelligence or Motivation More Important for Positive Higher-Educational Outcomes? Journal of Adolescent Research, Jan 2000; 15: 58 - 80.

21. James Popham. W. (1981), “Modern Educational Measurement” New Jersey, Prentine Hall, Inc., Englewood Cliffs.

22. Kothari, D.S., (1966) - Education and National Development: - Report of the Indian Education Commission, NCERT, New Delhi 
23. Lokesh Koul, (1990), "Methodology of Educational Research" (2 ${ }^{\text {nd }}$ ed.), New Delhi, Vikas Publishing house Pvt. Ltd.

24. Mouly George J. (1970) The Science of Educational Research, New York; Van Nostrand Rein hold Company.

25. National Policy on Education (1986), New Delhi, Ministry of Human Research, Development Govt. of India, May, 1986, 23.

26. Prohit. P.N. (2003) "Methodology of Educational Research - Tools and Techniques", Jaipur, Mangal Deep Publications.

27. Sherry K. Bain, R. Steve McCallum, Sherry Mee Bell, Jeff L. Cochran, and Stephani Choate Sawyer. Foreign Language Learning Aptitudes, Attitudes, Attributions, and Achievement of Postsecondary Students Identified as Gifted. Journal of Advanced Academics, Nov 2010; 22: 130 - 156.

28. Smith M.Fred, (1972), "Educational Measurement for the classroom teacher", ( $\left.2^{\text {nd }} e d.\right)$, New York, Harper Row, Publishers. 